\title{
Effects of cultivar and planting spacing on yield and yield components of garlic (Allium sativum L.)
}

\author{
Fahimeh Fakhar, Abbas Biabani, Mehdi Zarei, Ali Nakhzari Moghadam \\ Department of Crop Production, Faculty of Agriculture and Natural Resources, Gonbad-e-Kavous \\ University, Iran
}

\begin{abstract}
Planting spacing is the systematic evaluation of the farm area or any growing surface for crop production. In order to study the effect of varying planting patterns in two garlic (Allium sativum L.) cultivars, an experiment was carried out as a factorial design based on randomised complete block design with three replications in the farm of Gonbad-e-Kavous University during 20162017. The factors consisted of seven planting spacing $(12.5 \times 12.5$, $15 \times 15,17.5 \times 17.5,20 \times 20,22.5 \times 22.5,25 \times 25$ and $27.5 \times 27.5 \mathrm{~cm})$ and two cultivars (Tarom and Hamedan). The fresh bulb yield, bulb weight, clove weight, clove number of bulb, plant height, bulb diameter, bulb length, clove diameter, skin number and stem length were recorded. Results showed that there were significant differences between both planting spaces and cultivars in all variables assessed. The highest bulb yield $\left(19,014 \mathrm{~kg} \mathrm{ha}^{-1}\right)$ was recorded in Hamedan with the spacing $12.5 \times 12.5 \mathrm{~cm}$, while the lowest bulb yield $\left(7572 \mathrm{~kg} \mathrm{ha}^{-1}\right)$ was detected in Tarom with the spacing $27.5 \times 27.5 \mathrm{~cm}$. The highest number of cloves was produced by Hamedan under the $27.5 \times 27.5 \mathrm{~cm}$ arrangement. In addition, upon the correlation analysis between variables, the bulb weight showed the highest effect on garlic yield that bulb weight was negatively correlated with bulb yield $\left(r_{=}-0.60^{* *}\right)$. Generally, Cultivar Hamedan had a higher yield and yield components than Tarom and the spacing $12.5 \times 12.5 \mathrm{~cm}$ had a higher yield than the other spacing.
\end{abstract}

\footnotetext{
Correspondence: Abbas Biabani, Department of Crop Production, Faculty Agriculture and Natural Resources, Gonbad-e-Kavous University, Postal code 163, Iran.

E-mail: abbas.biabani@gonbad.ac.ir ; abs346@yahoo.com
}

Key words: Garlic; bulb yield; agronomic characteristics; planting spacing.

Received for publication: 30 July 2018

Revision received: 4 December 2018.

Accepted for publication: 18 December 2018.

(C) Copyright F. Fakhar et al., 2019

Licensee PAGEPress, Italy

Italian Journal of Agronomy 2019; 14:1303

doi:10.4081/ija.2019.1303

This article is distributed under the terms of the Creative Commons Attribution Noncommercial License (by-nc 4.0) which permits any noncommercial use, distribution, and reproduction in any medium, provided the original author(s) and source are credited.

\section{Introduction}

The long cultivation history of the Allium family has led to a wide range of cultivars belonging to different species (Golubkina et al., 2015), which serve as a food source, ornamentals and also incorporated into therapeutic products (Hsiao, 2016). Garlic is propagated by means of cloves and this vegetative propagation leads to infection by several viruses, which are called garlic viral complex (Manjunathago Wda et al., 2017).

Garlic is a medicinal plant in Iranian traditional medicine and its antimicrobial effects on food borne pathogens seem essential (Misaghi et al., 2016). This species is an essential vegetable that has been widely utilised as seasoning, flavouring, culinary and in herbal remedies as it is well known to contain an array of phytochemicals. Garlic is beneficial for its content of manganese, selenium, calcium, vitamins $\mathrm{B}_{1}$ and $\mathrm{B}_{6}$, tryptophan and protein (Suleria et al., 2015). According to the data provided by the Food Agricultural Organisation garlic yield in Iran is $12,016,600 \mathrm{~kg}$ ha ${ }^{1}$ and its cultivation area is 4514 ha (FAO, 2016).

Sustainable and resilient agricultural systems are needed to feed a growing human population. However, the current model of agricultural intensification which produces high yields has also resulted in a loss of biodiversity, ecological function and critical ecosystem services in agricultural landscapes (Landis, 2017). Different planting spacing within the row is practiced in both single and multiple rows pattern, depending on the characteristics and requirement of the crop, particularly its canopy expansion (Hetet et al., 2017). Ecological intensification, using land and resources in ways that minimise negative ecosystem impacts while maintaining agricultural productivity, has been proposed as a way to sustainably increase crop yields, but it remains under debate due to a lack of evidence (Pywell et al., 2015).

Planting density is one of the main factors that have an important role on growth, yield and quality of onion (Sekara et al., 2017). And it is important to accommodate the most appropriate number of plants per unit area of soil to obtain optimal yield as a consequence of the appropriate intensity and distribution of light within the vegetation (Fathi, 2006). Yield and quality of bulbs can be influenced by cultural practices and growing environments. The control of plant spacing is one of the cultural practices to control yield (Geremew et al., 2010). According to Jamroz et al. (2001) garlic responds best to a total yield $(14,166 \mathrm{~kg} / \mathrm{ha})$, were recorded with plant spacing of $8 \mathrm{~cm}$ between 4,12 and $16 \mathrm{~cm}$. Singh et al. (1990) studied six plant spacing that included: $30 \times 30$, $30 \times 45,30 \times 60,45 \times 45,45 \times 60$ and $60 \times 60 \mathrm{~cm}$. They found that the highest planting density $30 \times 30 \mathrm{~cm}$ gave a significantly higher yield.

In the view of this background the present was undertaken with the aim of exploring opportunities to maximise garlic productivity through the choice of appropriate planting spacing and cultivars. 


\section{Materials and methods}

The experiment was conducted at the experimental farm of Gonbad-e-Kavous (Golestan province, Iran) (37 $16^{\prime} \mathrm{N}$ latitude, $55^{\circ} 12^{\prime}$ E longitude of $45 \mathrm{~m}$ above sea level) in the years 20162017. The experimental protocol was based on the factorial combination between seven planting pattern $(12.5 \times 12.5,15 \times 15$, $17.5 \times 17.5,20 \times 20,22.5 \times 22.5,25 \times 25$ and $27.5 \times 27.5 \mathrm{~cm})$ and two cultivars (Tarom and Hamedan). Monthly temperature and rainfall data of the trial site during the experiment periods are shown in Table 1 .

The research was carried out on a clay-loam soil with EC 1.3 $\mathrm{dS} \cdot \mathrm{m}^{-1}, \mathrm{pH} 7.7$ and organic matter $1.44 \%$, which was ploughed and disked prior to cloves planting on 23 December 2016. The size of each experimental plot was difference wide and $3 \mathrm{~m}$ long, having $4 \mathrm{~m}$ rows. Before planting, $50 \mathrm{~kg}$ of nitrogen fertiliser per hectare was supplied. There was no incidence of either pest or yellow garlic rust on the crop throughout the growth period of trials, except for the weeds that were controlled manually by handpicking and hand hoeing. Bulbs were harvested when the leaves became yellow in colour and had started wilting.

\section{Data collection}

Plant height $(\mathrm{cm})$ : Data on plant height $(\mathrm{cm})$ were calculated with the help of ruler and plant height was measured from the soil surface to the top of the plant and average was worked out.

Bulb weight (g): Bulb fresh weight was measured after harvesting with the help of electric balance.

Bulb diameter, bulb length and clove diameter $(\mathrm{cm})$ : Bulb diameter, bulb length and clove diameter $(\mathrm{cm})$ were measured after harvesting with a digital Koulis (GuangLu model).

Clove number: Number of cloves per bulb was determined by counting the cloves per bulb, in selected samples.

Average yield $(\mathrm{kg})$ : Average yield was determined by weighing the collected bulbs from each plot and yield per hectare were calculated.

Chemical parameters: phenol traits Methanol extracts of sample (1 $\mathrm{g}$ sample in $10 \mathrm{cc}$ methanol) were used for determination of total phenol. Total phenol content was evaluated by colorimetric analyses using Folin-Ciocaltaue phenol reagent (Singleton and
Rossi, 1965). The total phenol content was expressed as mg galic acid equivalent/100 $\mathrm{g}$ of sample. The free radical-scavenging activity against DPPH radical was evaluated with the methods of Larrauri et al. (1998) with minor modification. In the presence of an antioxidant, the purple colour intensity of DPPH solution decays and the change of absorbance are followed spectrophotometrically at $517 \mathrm{~nm}$.

\section{Statistical analysis}

The data were subjected to the analysis of variance (ANOVA) using SAS version 9.2 and the mean separation was performed through the least significant difference test (LSD) at $5 \%$ and $1 \%$ probability level.

\section{Results and discussion}

The results showed that there were significant differences between planting spaces and effects on fresh bulb yield, mean bulb weight, clove weight, clove number and plant height (Table 2). As it is shown in Table 2, significant interactions were observed between fresh bulb yield, bulb weight, clove number and plant height parameters.

\section{Fresh bulb yield}

According to the data in Figure 1, the highest fresh bulb yield was obtained from cultivar Hamedan cultivar $\left(19,014 \mathrm{~kg} \mathrm{ha}^{-1}\right)$ and the lowest from cultivar Tarom cultivar $\left(7572 \mathrm{~kg} \mathrm{ha}^{-1}\right)$. The maximum and minimum fresh bulb yield were observed in $12.5 \times 12.5$ $\mathrm{cm}\left(19,014 \mathrm{~kg} \mathrm{ha}^{-1}\right)$ and $27.5 \times 27.5 \mathrm{~cm}\left(19,014 \mathrm{~kg} \mathrm{ha}^{-1}\right)$, respectively. The highest fresh bulb yield $\left(19,014 \mathrm{~kg} \mathrm{ha}^{-1}\right)$ was recorded in Hamedan with planting spacing $12.5 \times 12.5 \mathrm{~cm}$, while the lowest $\left(7,572 \mathrm{~kg} \mathrm{ha}^{-1}\right)$ was recorded in Tarom with planting spacing $27.5 \times 27.5 \mathrm{~cm}$. Total bulb yield of cultivar Hamedan increased from $12.5 \times 12.5 \mathrm{~cm}$ to $27.5 \times 27.5$ (Figure 1 ).

Olfati et al. (2016) also reported that the highest plant density corresponding to $15 \mathrm{~cm}$ between row, compared to 25 and $35 \mathrm{~cm}$ led to the highest total yield and the lowest bulb diameter and bulb weight. Other studies carried out on plant density showed: its direct

Table 1. Temperatures and rainfall during the growing season of 2016-2017.

\begin{tabular}{lcccccc}
\hline Month & December & January & February & March & April & May \\
Rainfall $(\mathrm{mm})$ & 39.99 & 46.10 & 48.00 & 46.90 & 54.80 & 1.80 \\
Temperature $\left({ }^{\circ} \mathrm{C}\right)$ Max. & 15.23 & 14.35 & 13.41 & 19.02 & 23.00 & 32.31 \\
\hline Temperature $\left({ }^{\circ} \mathrm{C}\right)$ Min. & 3.54 & 2.08 & 1.36 & 6.06 & 9.68 & 15.56 \\
\hline
\end{tabular}

Table 2. Analysis of variance (ANOVA) of effects of planting spacing and cultivars on yield and yield components of garlic.

\begin{tabular}{|c|c|c|c|c|c|c|}
\hline S.0.V. & DF & Fresh bulb yield & Bulb weight & $\begin{array}{l}\text { Mean square } \\
\text { Clove weight }\end{array}$ & Clove number & Plant height \\
\hline Replication & 2 & $103225.6^{\mathrm{ns}}$ & $0.92^{\mathrm{ns}}$ & $0.001^{\mathrm{ns}}$ & $0.23^{\mathrm{ns}}$ & $5.92^{\mathrm{ns}}$ \\
\hline Cultivar & 1 & $20365382.5^{* *}$ & $284.07 * *$ & $4.33^{* *}$ & $28.90^{* *}$ & $548.07^{* *}$ \\
\hline Planting spacing & 6 & $86302764.2^{* *}$ & $685.91^{* *}$ & $2.68 * *$ & $2.53^{* *}$ & $6.91 * *$ \\
\hline Interaction & 6 & $1256791.5^{* *}$ & $12.76^{* *}$ & $0.13 \mathrm{~ns}$ & $2.37^{* *}$ & $5.66^{*}$ \\
\hline Error & 26 & 140309.9 & 1.00 & 0.17 & 0.19 & 0.79 \\
\hline CV (\%) & - & 3.12 & 2.26 & 11.80 & 3.31 & 1.18 \\
\hline
\end{tabular}

ns, ${ }^{*}$ and ${ }^{* *}$ non-significant difference, significant difference at 0.05 and 0.01 probability levels, respectively. 
influence on yield (Castellanos et al., 2004). The increasing density resulted in significant yield increase, despite the decrease in many traits such as bulb weight, bulb diameter, number clove (Sedaghati, 2016). Similarly, Kilgori et al. (2007) reported that increasing plant spacing from 5 to $10 \mathrm{~cm}$ increased fresh bulb yield to $10,534 \mathrm{~kg} \mathrm{ha}^{-1}$, but a further increase to $20 \mathrm{~cm}$ resulted in a significant decline in the yield. Previous investigations showed that plant density increase results in higher yield up to a threshold depending on species as well as on crop system and growing season affecting light conditions (Caruso et al., 2013; Morano et al., 2017).

\section{Bulb weight}

Varying planting spacing significantly affected bulb weight and increasing planting density significantly decreases bulb weight; therefore, planting spacing $12.5 \times 12.5 \mathrm{~cm}$ caused lower bulb weight (Figure 2). Darabi et al. (2010) reported that the highest bulb yield and the lowest mean weight of bulb and clove were produced by 714 plant $\mathrm{m}^{-2}$ (density of $20 \times 7 \mathrm{~cm}$ ). This might be due to competition for growing indeed the bulb size may also be reduced under high plant density. Similar findings were reported by Hussen et al. (2014).

\section{Clove number}

The number of cloves per bulb influenced by treatments is shown in Figure 3. Decrease of planting density $(27.5 \times 27.5 \mathrm{~cm})$ increased number of cloves per bulb and cultivar Hamedan showed the highest clove number (Figure 3). Doro (2012) also reported that decrease of density significantly increases the cloves number per bulb as a result of increase of intra-row spacing from 5 to $20 \mathrm{~cm}$.

\section{Plant height}

As shown in Figure 4, using the planting spacing of $12.5 \times 12.5$ $\mathrm{cm}$ led to increase in plant height and cultivar Tarom had taller plants than Hamedan. Sedaghati et al. (2016) reported that increasing density enhanced plant height, due to increased light competition between plants.

Data presented in Table 3 suggest that plant spacing significantly affected garlic yield components such as bulb diameter, bulb length, clove diameter, skin number and length stem. No significant interactions were recorded and, moreover, the effects of plant spacing on mean skin number were not significant (Table 3 ).

Garlic grown under the $27.5 \times 27.5 \mathrm{~cm}$ spacing had increased bulb diameter, bulb length and clove diameter per bulb due to the vast space available for growth. Also at high density $(12.5 \times 12.5$ $\mathrm{cm})$ the stem length increased due to the high plant competition that (Table 4). Therefore, reducing the plant spacing increased the plant height of garlic but reduced single-plant parameters like weight bulb, bulb diameter and bulb length. Khajehpour (1993)

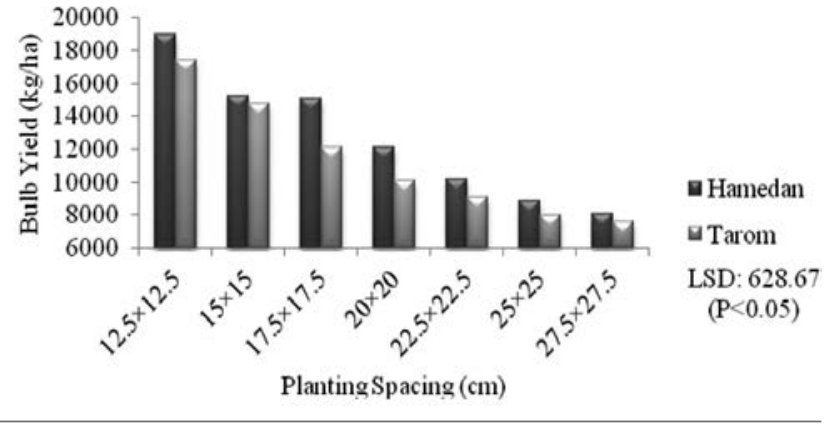

Figure 1. Interaction between cultivar and planting spacing on bulb yield of garlic.

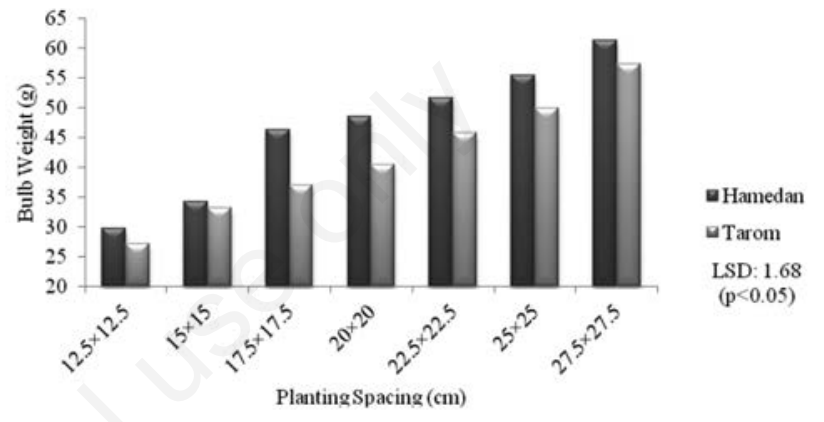

Figure 2. Interaction effects between cultivar and plant spacing on mean bulb weight of garlic.

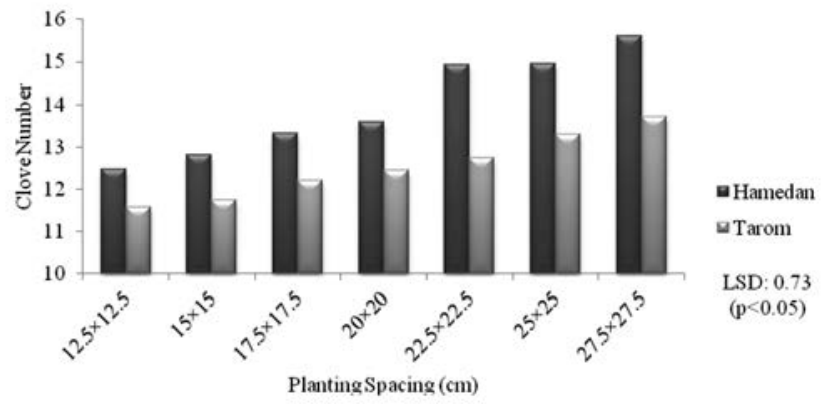

Figure 3. Interaction effects between cultivar and plant spacing on clove number per bulb of garlic.

Table 3. Analysis of variance (ANOVA) of effects of cultivar and planting spacing on agronomy properties of garlic.

\begin{tabular}{|c|c|c|c|c|c|c|}
\hline S.0.V. & $\mathrm{DF}$ & Bulb diameter & Bulb length & $\begin{array}{l}\text { Mean square } \\
\text { Clove diameter }\end{array}$ & Skin number & Length stem \\
\hline Replication & 2 & $1.60^{\mathrm{ns}}$ & $0.026^{\text {ns }}$ & $1.69^{n s}$ & $0.08^{\text {ns }}$ & $7.72^{*}$ \\
\hline Cultivar & 1 & $30.46^{*}$ & $11.94 * *$ & $14.02^{* *}$ & $0.92^{*}$ & $337.67^{* *}$ \\
\hline Planting Pattern & 6 & $120.11^{* *}$ & $37.07 * *$ & $3.94^{* *}$ & $0.23^{\mathrm{ns}}$ & $6.84^{*}$ \\
\hline Interaction & 6 & $1.25^{\mathrm{ns}}$ & $1.45^{\mathrm{ns}}$ & $0.18^{\text {ns }}$ & $0.08^{\text {ns }}$ & $7.95^{\mathrm{ns}}$ \\
\hline Error & 26 & 4.86 & 0.53 & 0.27 & 0.02 & 1.70 \\
\hline CV (\%) & - & 4.71 & 2.27 & 4.63 & 10.10 & 5.21 \\
\hline
\end{tabular}

ns, ${ }^{*}$ and ${ }^{* *}$ non-significant difference, significant difference at 0.05 and 0.01 probability levels, respectively. 
reported that at higher densities the increased plant competition for light resulted in plant height enhancement, consistently with our results.

The results reported in Table 5 suggest that cultivar Hamedan has higher values of bulb diameter, bulb length and clove diameter, but Tarom has more remarkable clove weight and stem length (Table 5).

\section{Chemical analysis}

The chemical analysis results investigated are shown in Table 6 .The results showed that there were significant differences interaction between planting spacing and cultivar effects on total phenol and antioxidant activity.

The highest total phenol of Hamedan cultivar was obtained from $27.5 \times 27.5 \mathrm{~cm}(12.30 \mathrm{mg} / \mathrm{g} \mathrm{DW})$ while the lowest total phenol was obtained from $12.5 \times 12.5 \mathrm{~cm}(7.94 \mathrm{mg} / \mathrm{g}$ DW) Tarom cultivar (Figure 5). The highest antioxidant capacity for two cultivar were obtained from $27.5 \times 27.5 \mathrm{~cm}$, but the highest antioxidant capacity except Hamedan that it was related to $27.5 \times 27.5 \mathrm{~cm}$ planting spacing $(96.85 \%$ DPPH reduction) and the lowest antioxidant capacity (75.91\% DPPH) of Tarom cultivar was obtained from planting spacing $12.5 \times 12.5 \mathrm{~cm}$ (Figure 6). More bulb size obtained from wider spacing $(27.5 \times 27.5 \mathrm{~cm})$ may be due to vigorous plant, dues bulb store more food for vegetative as well as reproductive growth and quality of garlic. Light is important source of photosynthesis for crop, wider spaced plant get proper light intensity and nutrient (Kahsay et al., 2014; Muneer et al., 2017).

\section{Correlation analysis}

The correlation coefficient of the studied traits under different planting spacing and cultivar are presented in Table 7. In general, the purpose of getting the correlation between traits was to determine which attribute is more correlated with yield. The correlation coefficient between bulb yield and bulb weight, bulb diameter, bulb length, clove diameter, clove weight, plant height and stem length were significant and negative.

Correlation analysis (Table 7) showed that the relationship between bulb weight with bulb diameter, bulb length and clove weight was significantly positive: by decreasing plant spacing, bulb weight, bulb diameter, bulb length and clove weight of garlic

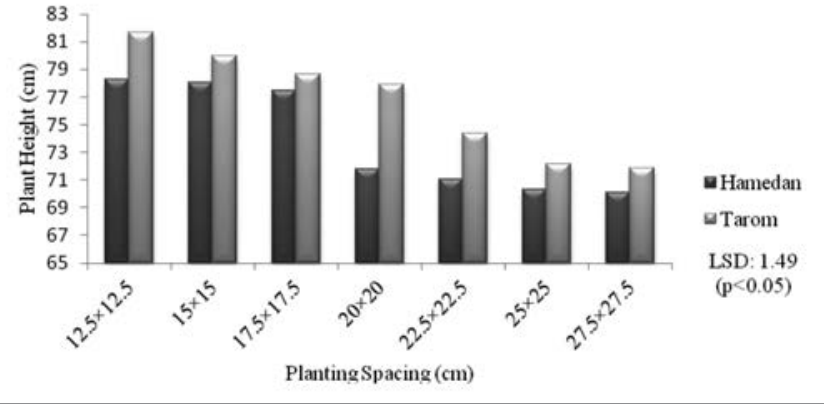

Figure 4. Interaction effects between cultivar and planting spacing on plant height of garlic.

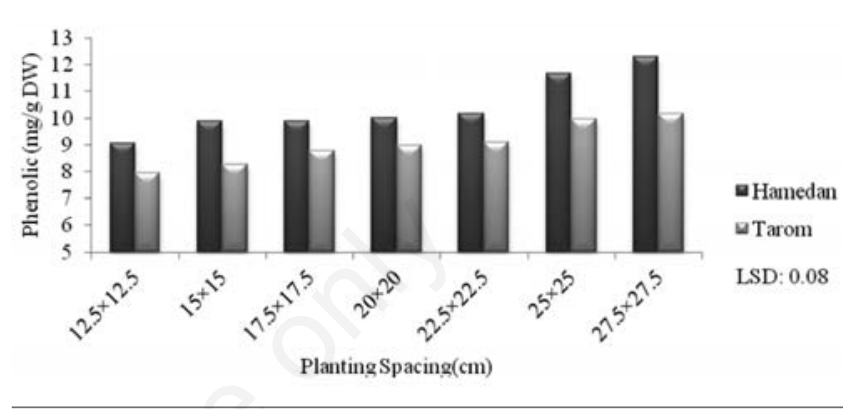

Figure 5. Interaction effects between cultivar and planting spacing on phenolic of garlic.

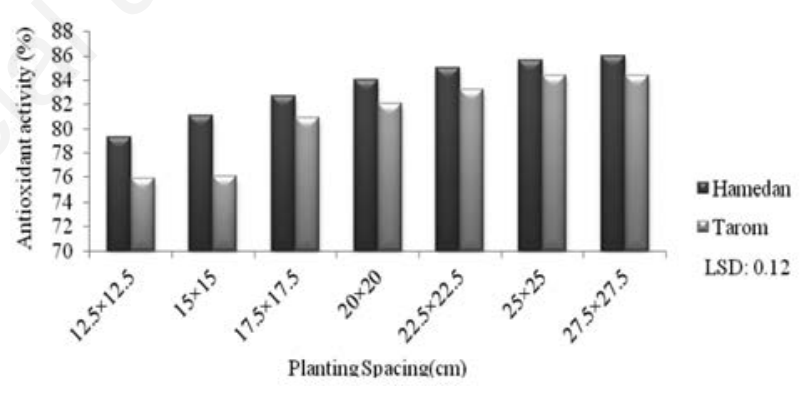

Figure 6. Interaction effects between cultivar and planting spacing on antioxidant activity of garlic.

Table 4. Mean comparison of morphological properties of garlic under different planting spacing.

\begin{tabular}{|c|c|c|c|c|c|}
\hline $\begin{array}{l}\text { Planting spacing } \\
(\mathrm{cm})\end{array}$ & $\begin{array}{l}\text { Bulb diameter } \\
(\mathrm{mm})\end{array}$ & $\begin{array}{l}\text { Bulb length } \\
(\mathrm{mm})\end{array}$ & $\begin{array}{l}\text { Clove weight } \\
\text { (g) }\end{array}$ & $\begin{array}{l}\text { Clove diameter } \\
\text { (mm) }\end{array}$ & $\begin{array}{l}\text { Stem length } \\
\text { (cm) }\end{array}$ \\
\hline $12.5 \times 12.5$ & 40.16 & 28.75 & 2.68 & 2.68 & 26.16 \\
\hline $15 \times 15$ & 41.38 & 29.16 & 2.81 & 2.81 & 26.05 \\
\hline $17.5 \times 17.5$ & 46.08 & 31.85 & 3.48 & 3.48 & 26.03 \\
\hline $20 \times 20$ & 47.98 & 33.01 & 3.49 & 3.49 & 24.96 \\
\hline $22.5 \times 22.5$ & 49.97 & 33.30 & 3.83 & 3.83 & 24.37 \\
\hline $25 \times 25$ & 50.18 & 33.38 & 4.32 & 4.32 & 23.88 \\
\hline $27.5 \times 27.5$ & 51.63 & 35.75 & 4.40 & 12.50 & 27.70 \\
\hline LSD $(P \leq 0.05)$ & 2.61 & 0.86 & 0.50 & 0.62 & 1.54 \\
\hline
\end{tabular}

Table 5. Mean comparison of morphological properties of the two garlic cultivars examined.

\begin{tabular}{lccccc} 
Cultivar & $\begin{array}{c}\text { Bullo diameter } \\
(\mathrm{mm})\end{array}$ & $\begin{array}{c}\text { Bulb length } \\
(\mathrm{mm})\end{array}$ & $\begin{array}{c}\text { Clove weight } \\
(\mathrm{g})\end{array}$ & $\begin{array}{c}\text { Clove diameter } \\
(\mathrm{mm})\end{array}$ & $\begin{array}{c}\text { Stem length } \\
(\mathrm{cm})\end{array}$ \\
Tarom & 45.92 & 31.63 & 3.90 & 10.70 & 27.86 \\
Hamedan & 47.62 & 32.70 & 3.25 & 11.86 & 22.19 \\
\hline LSD $(\mathrm{P} \leq 0.05)$ & 1.39 & 0.46 & 0.26 & 0.33 & 0.82 \\
\hline
\end{tabular}


Table 6. Analysis of variance (ANOVA) of effects of cultivars and planting spacing on chemical properties of garlic.

\begin{tabular}{lccc} 
S.0.V. & DF & Total phenol & Antioxidant activity \\
Replication & 2 & $0.10^{\text {ns }}$ & $0.09^{\text {ns }}$ \\
Cultivar & 1 & $27.83^{* *}$ & $12.08^{* *}$ \\
\hline Planting spacing & 6 & $5.47^{* *}$ & $4.24^{* *}$ \\
Interaction & 6 & $1.06^{*}$ & $1.51^{*}$ \\
\hline Error & 26 & 0.13 & 0.06 \\
CV $(\%)$ & & 1.11 & 3.17 \\
\hline
\end{tabular}

ns, ${ }^{*}$ and ${ }^{* *}$ non-significant difference, significant difference at 0.05 and 0.01 probability levels, respectively.

Table 7. Correlation coefficients between the variables assessed.

\begin{tabular}{|c|c|c|c|c|c|c|c|c|c|c|}
\hline & EY & BW & BD & BL & $\mathrm{CW}$ & CD & CN & PH & SL & SN \\
\hline EY & 1 & & & & & & & & & \\
\hline BW & $-0.60 * *$ & 1 & & & & & & & & \\
\hline $\mathrm{BD}$ & $-0.56^{* *}$ & $0.85^{* *}$ & 1 & & & & & & & \\
\hline BL & $-0.53^{* *}$ & $0.72^{* *}$ & $0.88^{* *}$ & 1 & & & & & & \\
\hline $\mathrm{CW}$ & $-0.54^{* *}$ & $0.73^{* *}$ & $0.75^{* *}$ & $0.63^{* *}$ & 1 & & & & & \\
\hline $\mathrm{CD}$ & $-0.25^{\mathrm{ns}}$ & $0.54^{* *}$ & $0.43^{* *}$ & $0.32 *$ & $0.45^{* *}$ & 1 & 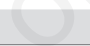 & & & \\
\hline $\mathrm{CN}$ & $0.02^{\mathrm{ns}}$ & $0.22^{\mathrm{ns}}$ & $0.17^{\mathrm{ns}}$ & $0.17^{\mathrm{ns}}$ & $-0.12^{\mathrm{ns}}$ & $0.17^{\mathrm{ns}}$ & 1 & & & \\
\hline $\mathrm{PH}$ & $-0.05^{\mathrm{ns}}$ & $0.21^{\mathrm{ns}}$ & $0.34^{*}$ & $0.28^{\mathrm{ns}}$ & $0.39 *$ & $-0.25^{\mathrm{ns}}$ & $-0.32^{*}$ & 1 & & \\
\hline SL & $-0.09^{\mathrm{ns}}$ & $0.22^{\mathrm{ns}}$ & $0.31^{*}$ & $0.30^{*}$ & $0.38 *$ & $-0.29^{\mathrm{ns}}$ & $-0.35^{*}$ & $0.79 * *$ & 1 & \\
\hline SN & $0.28^{\mathrm{ns}}$ & $-0.17^{\mathrm{ns}}$ & $-0.10^{\text {ns }}$ & $-0.24^{\mathrm{ns}}$ & $0.13^{\text {ns }}$ & $0.30^{\mathrm{ns}}$ & $0.06^{\mathrm{ns}}$ & $0.26^{\mathrm{ns}}$ & $0.21^{\mathrm{ns}}$ & 1 \\
\hline
\end{tabular}

ns, * and ** non-significant difference, significant difference at 0.05 and 0.01 probability levels, respectively. EY, economic yield; BW, bulb weight; BD, bulb diameter; BL, bulb length; CW, clove weight; CD, clove diameter; CN, clove number; PH, plant height; SL, stem length; SN, skin number.

increases. Tesfaye Gebeyehu (2016) reported that in onion umbel diameter, seed yield and seed weight were negatively correlated with yield.

\section{Conclusions}

We compared and characterised the bulb yield and yield components of two garlic cultivars differing in planting patterns. Our results showed that cultivar Hamedan has higher total bulb yield than cultivar Tarom. Furthermore, the planting spacing $12.5 \times 12.5$ $\mathrm{cm}$ allowed to reach the maximum fresh bulb yield of garlic. Increasing plant spacing resulted in higher yield components due to better light and nutritional resources available. However, further investigations will be needed to assess garlic bulb yield and related components under additional environmental and farming management factors of bulb yield and yield component and testing will be needed to improve and expand its capability to include additional environmental and agricultural management factors.

\section{References}

Caruso G, Carputo D, Conti S, Borrelli C, Maddaluno P, Frusciante L, 2013. Effect of mulching and plant density on out of season organic potato growth, yield and quality. Sci. Hortic. 27:115-21.

Castellanos JZ, Vargas-Tapia P, Ojodeagua JL, Hoyos G, 2004. Garlic productivity and profitability as affected by seed clove size, planting density and planting method. Sci. Hortic. 39:1272-7.

Darabi A, Dehghani A, 2010. Effect of planting data and planting density on yield, yield components and rust disease severity in Ramhormoz selected garlic in Behbahan region. Seed Plant Prod. J. 26:43-55.

Doro AK, 2012. Response of garlic (Allium sativum L.) to intrarow spacing at ajiwa irrigation site of katsina state-nigeria. J. Res. Natl. Dev. 10:103-7.

FAO, 2016. Food and Agriculture Organisation. Statistics. Available from: http://faostat.fao.org/site/567/Default

Fathi G, 2006. Effect of planting pattern and population density on light extinction coefficient, light inter caption and grain yield of sweet corn. Agric. Sci. J. 12:131-43.

Geremew A, Teshome A, Kasaye T, Amenti C, 2010. Effect of intra row spacing on yield of three onion (Allium cepa L.). Hortic. J. 2:7-11.

Golubkina NA, Nadezhkin SM, Agafonov AF, Kosheleva OV, Molchanova AV, Russo G, Cuciniello A, Caruso G, 2015. Seed oil content, fatty acids composition and antioxidant properties as affected by genotype in Allium cepa L. and perennial onion species. Adv. Hortic. Sci. 29:199-206.

Hetet MNS, Soomro RN, Bo H J, 2017. Effects of different planting pattern of maize (Zea mays L.) and soybean (Glycine max L.) intercropping in resource consumption on fodder yield and silage quality. Am. J. Plant Sci. 8:666-79.

Hussen S, Medhin F, Tadesse A, 2014. Effect of intra row spacing on growth performance of garlic (Allium sativum L.) at the experimental site of Wollo university, south Wollo, Ethiopia. Eur. J. Agric. For. Res. 2:54-61. 
Jamroz M, Ishtiaq M, Naeem N, Muhammad N, Jamiher B, Iqbal J, 2001. Effect of different planting dates and spacing on growth and yield of garlic. Bio. Sci. 1:206-8.

Kahsay Y, Belew D, Abay F, 2014. Effect of intra-row spacing on plant growth and yield of onion varieties (Allium cepa L.). Afri. Agric. Res. 9:931-40.

Khajehpour MR, 1993. Principal of agronomy. Isfahan University of Technology Publication, Iran, 412 pp.

Kilgori M, Magaji M, Yakubu A, 2007. Effect of plant spacing and date of planting on yield of two garlic (Allium sativum L.) cultivars in Sokoto, Nigeria. Am. Eur. J. Agric. Environ. Sci. 2:153-7.

Larrauri JA, Sanchez-Moreno C, Saura-Calixto F, 1998. Effect of temperature on the free radical scavenging capacity of extracts from red and white grape pomace peels. J. Agric. Chem. 46:2694-7.

Landis DA, 2017. Designing agricultural landscapes for biodiversity based. Basic Appl. Ecol. 1-12.

Manjunathago Wda DC, Gopal J, Archana R, Asiya KR, 2017. Virus-free seed production of garlic (Allium sativum L.). Inter. J. Curr. Micro. App. Sci. 6 :2446-56.

Misaghi A, Taheri M, Akhondzadeh A, Modaresi MH, Gandomi H, Khosravi P, Talebi F, Heshmati A, 2016. Garlic essential oil effect on E. coli growth and production of Shigotoxin. J. Vet. Res. 71:41-7.

Morano G, Amalfitano C, Sellitto M, Cuciniello A, Maiello R, Caruso G, 2017. Effects of nutritive solution electrical conductivity and plant density on growth, yield and quality of sweet basil grown in gullies by subirrigation. Adv. Hort. Sci. 31:25-30.

Muneer N, Hussain M, Jamil Ahmad M, Khan N, Hussain N, Hussain B, 2017. Effect of planting density on growth, yield and quality of garlic at Rawalakot, Azad Kashmir. Inter. J. Agron. Agric. Res. 10:42-51.
Olfati AJ, Mahdieh Najafabadi MB, Rabiee M, 2016. Between row spacing and local accession on the yield and quality of garlic. Comun. Sci. 7:112-21.

Pywell R, Heard M, Woodcock B, Hinsley S, Ridding L, Nowakowski M, Bullock J, 2015. Wildlife-friendly farming increases crop yield: evidence for ecological intensification. Proc. R. Soc. B. 282:20151740.

Singh D, Singh H, Gill SS, Chadha ML, 1990. Effect of plant density on onion seed yield. An. Biol. 6:171-2.

Singleton VL, Rossi JR, 1965. Colorimetry of total phenolics with phosphomolybdic-phosphotungestic acid reagent. Am. J. Enol. Vitic. 16:144-58.

Sedaghati AR, 2016. The effect of plant density and sowing date on quantity and quality of two garlic ecotyps. M.Sc. Thesis, Islamic Azad University, 60 p.

Sedaghati AR, Kafi M, Rezvan Bidokhti SH, Akbari SH, 2016. Effect of planting date and density on yield and yield components and allicin content of two garlic (Allium sativum L.) ecotypes. Iranian J. Medic. Arom. Plants. 31:1024-34.

Sekara A, Pokluda R, Del Vacchio L, Somma S, Caruso G, 2017. Interactions among genotype, environment and agronomic practices on production and quality of storage onion (Allium cepa L.). Review. Hort. Sci. 44:21-42.

Suleria HAR, Sadiq Butt M, Khalid N, Sultan S, Raza A, Aleem M, Abbas M, 2015. Garlic (Allium sativum): diet based therapy of 21 st century-a review. Asian Pac. J. Trop. Dis. 5:271-8.

Tesfaye Gebeyehu, M, 2016. Effect of planting time on growth, yield components, seed yield and quality of onion (Allium cepa L.) at tehuledere district, north eastern Ethiopia. M.Sc. Thesis, Jimma Univ., Ethiopia, 56 p. 